\title{
Simulation study on polishing of gear surfaces in non-Newtonian fluid
}

\author{
Duc Nam Nguyen ${ }^{1, *}$, Hung Anh Ly ${ }^{2,3}$, Cong-Truyen Duong ${ }^{1}$
}

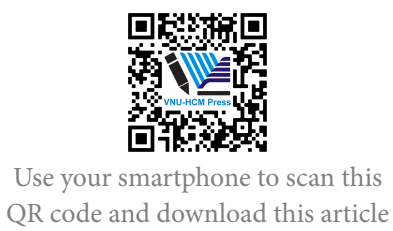

${ }^{1}$ Faculty of Mechanical Engineering, Industrial University of Ho Chi Minh City, Ho Chi Minh City, Vietnam

${ }^{2}$ Faculty of Transportation Engineering, Ho Chi Minh City University of Technology, Ho Chi Minh City, Vietnam

${ }^{3}$ Vietnam National University, Ho Chi Minh City, Vietnam

Correspondence

Duc Nam Nguyen, Faculty of Mechanical Engineering, Industrial University of $\mathrm{Ho}$ Chi Minh City, Ho Chi Minh City, Vietnam

Email: nguyenducnam@iuh.edu.vn

History

- Received: 10-01-2020

- Accepted: 13-10-2020

- Published: 22-10-2020

DOI : 10.32508/stdjet.v3i3.658

\section{Check for updates}

\section{Copyright}

(c) VNU-HCM Press. This is an openaccess article distributed under the terms of the Creative Commons Attribution 4.0 International license.

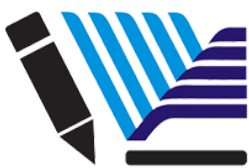

VNU-HCM Press

\begin{abstract}
The non-Newtonian fluid is one type of shear thickening fluid which applied to process the complicated products. In this study, the new method of shear thickening fluid polishing (STFP) was used to polish the alloy steel SCM435 gears and the principle and performance of polishing process were also introduced. In the polishing process, the inclination angle of gears was believed to be an important parameter that affects the pressure and surface quality at different position on the tooth surfaces because it determines the contact between the polishing fluid and the tooth surface of the gear. The influence of the inclination angles on the pressure distribution and characteristics of fluid flow was performed by simulation process. The inclination angles of $0,4,8,12$, 16,20 and 24 degrees were chosen in this study. As a result, the best inclination angle of gears is about 16 degree in the machining process. The tooth surfaces of gear have been in contact with the polishing fluid and the produced pressure reaches of $14.88 \mathrm{kPa}$. In addition, the influence of polishing speed on pressure were carried out in this study when inclination angle was established about 16 degree. The produced pressure on tooth surfaces increased with increasing the polishing speed. The results indicated that the different polishing speed also greatly affects the surface quality and machining efficiency. Therefore, the suggested machining method can become a suitable processing method for polishing the complicated products.
\end{abstract}

Key words: Non-Newtonian fluid, Gear surface, Surface roughness, Inclination angle, Pressre, Polishing speed

\section{INTRODUCTION}

The gears have been widely used in the fields of mechanics, industrial machinery, and engines. It is used for converting the power and speed of the machines. They can transfer power from small to large, and low to high speeds. The gear transmitters have a lot of advantages, such as a stable gear ratio, quiet operation but not complicated construction, and small size. Usually, the forming or the generating method were used to fabricate the gears. In the forming method, the machining process was carried out with a modular milling tool that matches with the gear module ${ }^{1}$. Besides, the gears can also be machined by hobs, gear shaper tools, and rack-type generating tools in the generating method ${ }^{2-7}$.

For improving the machining performance of machining process, the end-mill was applied to cut the gears using computer numerically controlled (CNC) machine. The cutting tools movement were set up and calculated with Computer Aided-Manufacturing (CAM) program. Therefore, the machining period of the gears will be reduced and the productivity will be increased $^{8-11}$.

In order to increase the high load capacity, good strength and high precision transmission of the gears, the gear surfaces are often tempered and treated to achieve the appropriate hardness ${ }^{12-14}$. However, the surface quality of the gears has been reduced after the heat treatment processing ${ }^{15-17}$. Therefore, the gear surface after heat treatment processing will be grinded to improve the surface quality and the time-life of the gear. The cutting process was performed simultaneously by many abrasive grains with different cutting edges randomly distributed on the surface of the grinding wheels. As a result, the surface roughness of the gear was achieved about Ra of $1.0-0.2 \mu \mathrm{m}$ during grinding process ${ }^{18-20}$. However, the finished grinding process of gear surfaces will be faced many problems due to the complicated shape of the gear. Consequently, this process requires not only complex machining trajectory but also high machining conditions. The result is a large machining time and high cost for the grinding process.

In the working process of gears, the corrosion, fatigue and wear resistance were depend on the surface roughness of gear. It is an important indicator for evaluating the quality of tooth surfaces of gear. Therefore, in this study, the shear thickening fluid polishing (STFP) method was carried out and used to improve the surface roughness of gear. The suggested method 
is one type of the non-Newtonian fluids and applied to polish the complicated shapes. In this method, the fluid pressure is generated by shear thickening of the polishing fluid when it is moved on the machining process $^{21,22}$. As the results, the surface quality of gear and efficiency of the machining process were greatly improved. The machining parameters such as inclination angles and polishing speeds are simulated to evaluate their influence on pressure distribution and flow characteristics on the gear surface. According to the simulation results, the suitable inclination angle of workpiece and polishing speed values were determined for increasing the pressure area which generated on the tooth surface of the gear in polishing process.

\section{MODELING OF STFP PROCESS}

\section{STFP process}

The STFP method is based on the pressure of polishing fluid that contact with the workpiece surfaces to remove the material. The behavior of this polishing fluid has the properties as a non-Newtonian fluids. Therefore, the viscosity of the polishing fluid is changed during machining process. This viscosity will increase with increasing of the shear rate under the appropriate value of shear rate ${ }^{23}$.

In recent years, the STFP method has been studied and applied in the polishing process of complicated products $^{24-28}$. This machining method has been used in various industrial fields including human body armor $^{29}$, smart structures, shock absorbing devices ${ }^{30}$, and fine polishing ${ }^{31,32}$. This indicates that the STFP offers high advantageous and efficiency in the manufacturing process.

The characteristics of machining process of gear which using the STFP method are presented in Figure 1. In this process, the polishing slurry consists of abrasive particles, polymers and dispersants which distributed in the mixture liquid. The shear thickening area is produced when the relative velocity between the polishing fluid and workpiece is changed. The high shear rate can be achieved under suitable relative velocity conditions. Therefore, it will create a higher cutting force in the shear thickening area. At higher shear rate, the particles in the polishing fluid will contacted together in suspension form. So, the polishing fluid will be like a cutting tool with high elasticity and flexibility. The abrasives covered in polymer particles are considered as a micro-cutters that creeps and rubs with the gear surface in the polishing process. As a result, the scratches on the gear surface are removed by the abrasive particles. The fluid flow and material removal mechanism of the machining process are found by investigating the rheological behavior of the STFP.

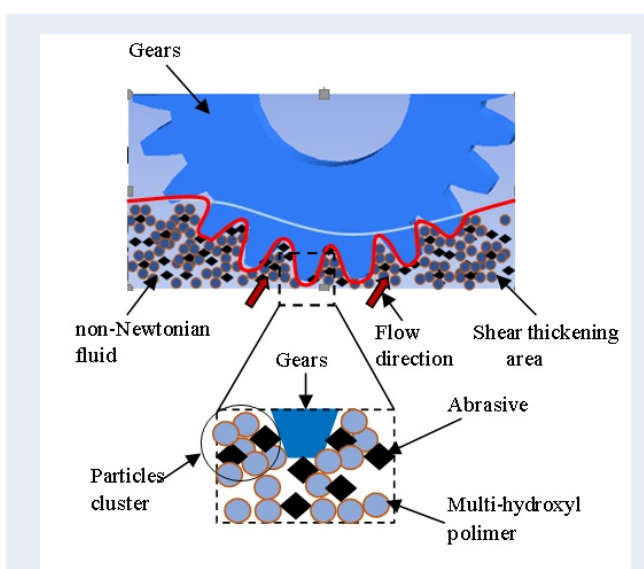

Figure 1: Characteristics of the STFP process

In the STFP method, a good surface quality is achieved when the polshing fluid touches and covers all the workpiece surfaces. In addition, the hydrodynamic force generated in the machining process must be reach a sufficiently value. Therefore, the advantage of the STFP method is that the complicated surfaces can be polished by a simple processing with high efficiency.

\section{FE simulation model}

According to the STFP process, the finite element (FE) simulation for gear was modeled as indicated in Figure 2. From the previous studies, the simulation conditions were selected in accordance with the experimental conditions, which could be applied in future works. The radius and speed of polishing tank are $300 \mathrm{~mm}$ and $1.85 \mathrm{~m} / \mathrm{s}$ respectively. The gear diameter used in the simulation model is chosen of $81 \mathrm{~mm}$. During the FE simulation, the initial parameters include the inlet, the outlet, the polishing tank values, inclination angle and the gear diameter were set as presented in Figure 2. The polishing fluid characteristic is chosen of the non-Newtonian power law with consistency index of $\mathrm{K}=0.62$ and viscosity index of $\mathrm{n}$ $=1.5^{22}$. The simulation of fluid flow is established by using the ANSYS workbench. No slip boundary condition was obligated all the remaining walls and the pressure value was set to be constant at the outlet. The simulation model is meshed with a total of 30370 nodes and 154976 elements, as shown in Figure 3. 


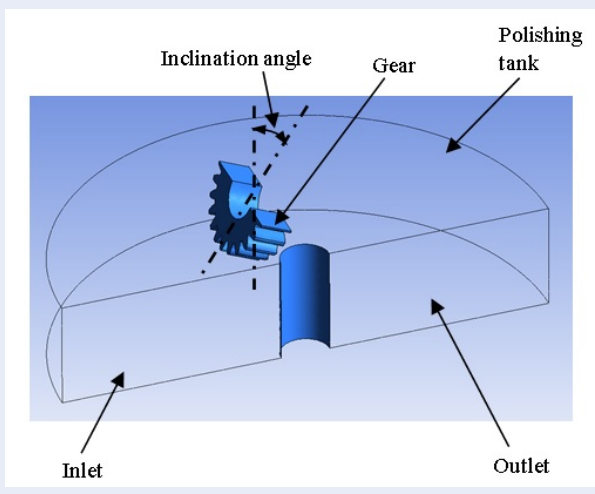

Figure 2: The conditions of FE simulation model

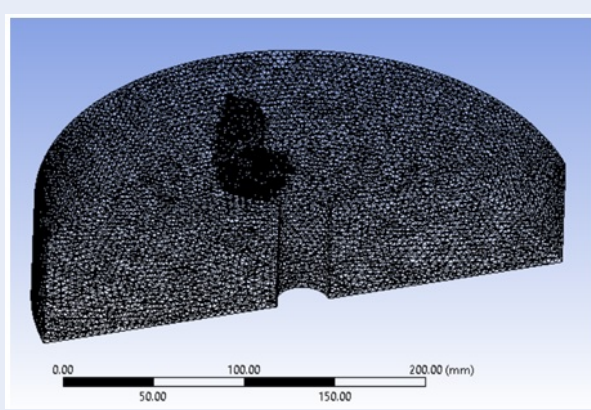

Figure 3: Element meshing model

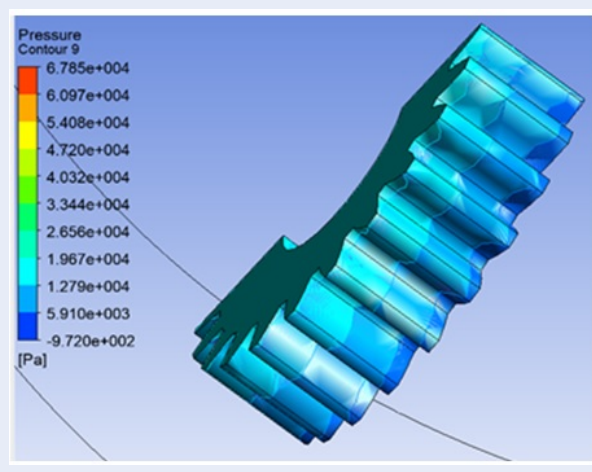

Figure 4: FEA results ofdistributed pressure area $\left(0^{0}\right)$

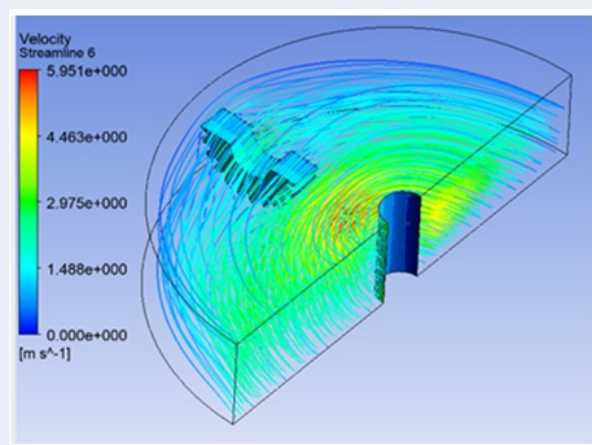

Figure 5: Streamline and velocity of $\operatorname{STFP}\left(0^{0}\right)$

The IA of gears was chosen about $4^{0}$ in this section. The generated pressure on the tooths were indicated in Figure 6.

\section{nation angles (IA)}

In this section, the finite element analysis (FEA) of pressure distribution on the gear surface during machining with varying inclination angles (IA) is performed and discussed.

- IA of 0 degree

First, the gear was set to be stationary and perpendicular to the polishing fluid. When the polishing fluid is moved, the gears would be touch with the abrasives. As a result, the pressure was generated on the gear surfaces, as presented in Figure 4.

From the FEA results in Figure 4, the generated pressure is only distributed at the front of the gear. The largest pressure value is $13.91 \mathrm{kPa}$. However, the generated pressure on the rear of the gear is quite small. This shows that the back of the gear is unreachable with the abrasive particles of the polishing fluid.

The streamline and velocity of the machining fluid flow were shown in Figure 5.

- IA of 4 degree

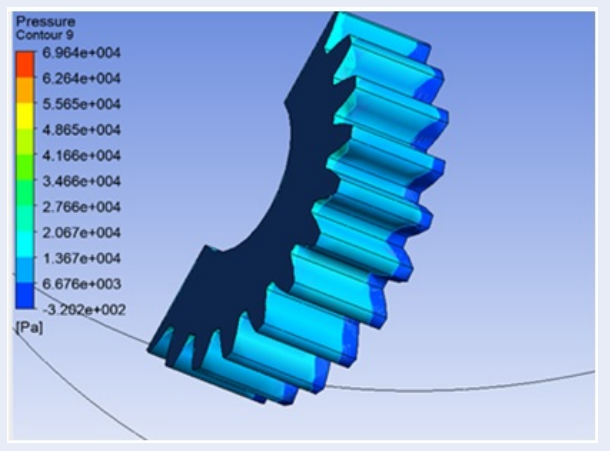

Figure 6: FEA results of distributed pressure area $\left(4^{0}\right)$

From the Figure 6, the generated pressures were still mainly concentrated in the front of the tooths. The highest pressure value is $13.95 \mathrm{kPa}$ in this case. Compared with inclination angle of 0 degree, the pressure 
value at the back of the workpieces was greater. This indicates that the contact area between the workpiece and the polishing fluid tends to increase with increasing the IA of the workpiece.

The streamline and velocity of the machining fluid flow were presented in Figure 7.

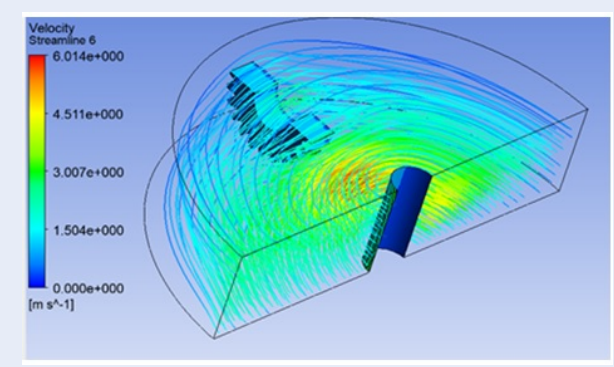

Figure 7: Streamline and velocity of STFP $\left(4^{0}\right)$

\section{- IA of 8 degree}

For this section, the IA of gears was set to be 8 degree. The change of the generated pressure on the workpiece surfaces was indicated in Figure 8.

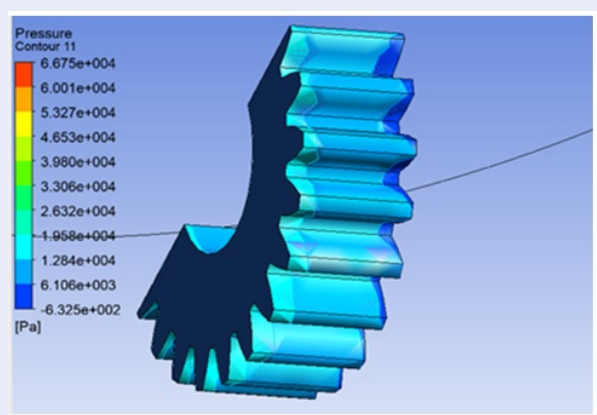

Figure 8: FEA results of distributed pressure area $\left(8^{0}\right)$

As shown in Figure 8, the pressure zone was extend along the surface of the gear with the maximum pressure value of $14.41 \mathrm{kPa}$. The rear part of the gear surfaces were more touch with the slurry during machining process. As a result, the pressure value at the back of the tooth was significantly improved.

The streamline and velocity of the machining fluid flow were demonstrated in Figure 9.

- IA of 12 degree

The IA of the gears was modified to $12^{0}$ during the simulation process. The change of the generated pressure on the workpiece surfaces was presented in Figure 10. The pressure zone was increased on the surface of tooths with the largest pressure value of 14.65

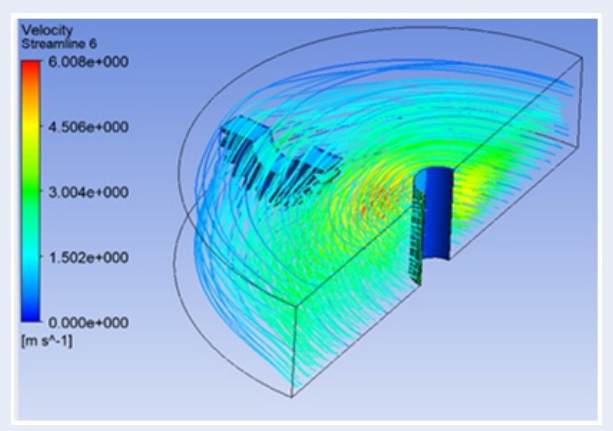

Figure 9: Streamline and velocity of STFP $\left(8^{0}\right)$

$\mathrm{kPa}$. The pressure values at the back of the workpiece surfaces tend to increase steadily. The gear surfaces were more touch with the abrasive slurry and pressure value was $5.94 \mathrm{kPa}$.

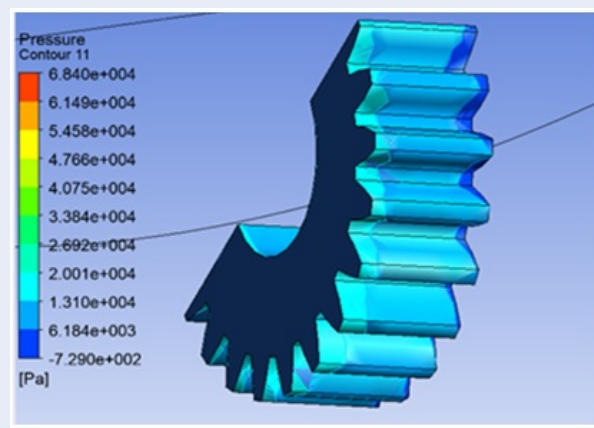

Figure 10: FEA results of distributed pressure area $\left(12^{0}\right)$

The streamline and velocity of the machining fluid flow were shown in Figure 11.

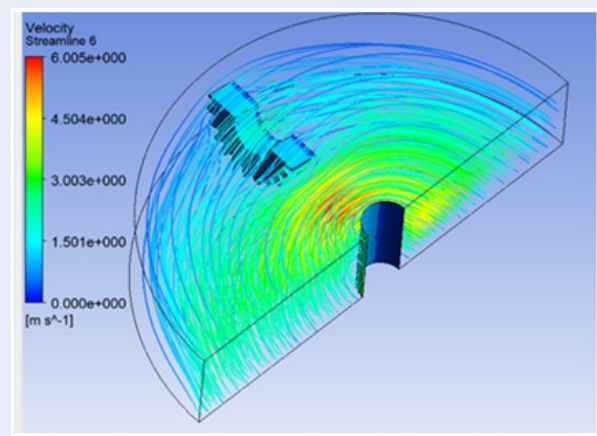

Figure 11: Streamline and velocity of STFP $\left(12^{0}\right)$

- IA of 16 degree 
For this FE simulation, the IA of gear was set to be $16^{0}$. The expansion of the generated pressure on the gear surfaces was shown in Figure 12.

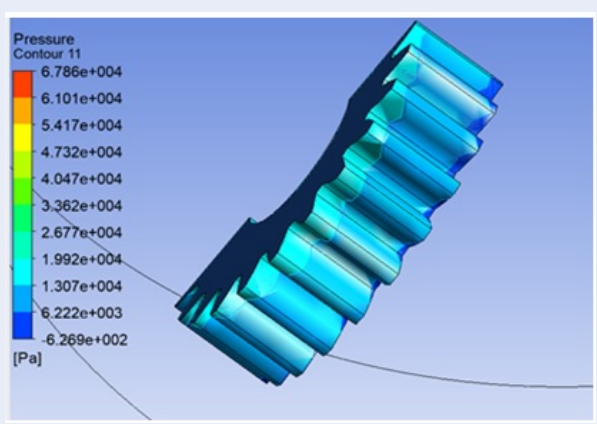

Figure 12: FEA results of distributed pressure area $\left(16^{0}\right)$

From the FEA results, the largest pressure value can be reduced when the IA of workpiece exceeds the appropriate value. The largest pressure at the ahead of the gear surfaces was $14.88 \mathrm{kPa}$. The rear area of the gear surfaces was in full touch with the abrasives slurry and the pressure value was still increasing steadily.

The streamline and velocity of the machining fluid flow were presented in Figure 13.

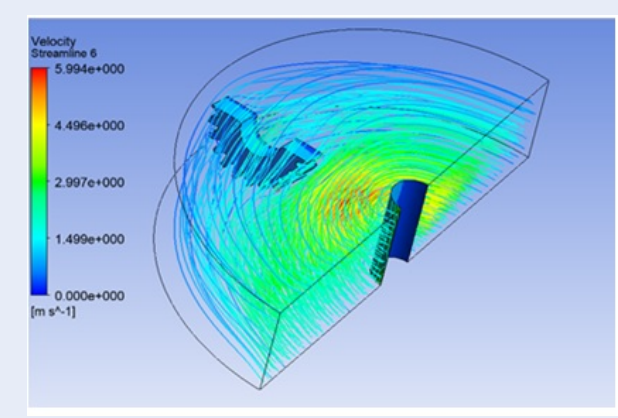

Figure 13: Streamline and velocity of STFP $\left(16^{0}\right)$

\section{- IA of 20 degree}

From this section, the IA of gear was changed to $20^{\circ}$. The expansion of the generated pressure on the gear surfaces was presented in Figure 14.

The expansion of the generated pressure on the gear surfaces has a small change as compared with FEA results of IA of $16^{0}$. The highest pressure value can be reached about $15.1 \mathrm{kPa}$. However, the pressure value in the rear part of workpiece surfaces was decreased. The streamline and velocity of the machining fluid flow were illustrated in Figure 15.

- IA of 24 degree

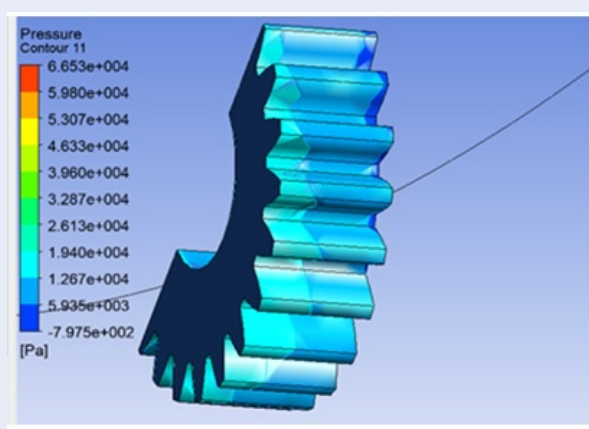

Figure 14: FEA results of distributed pressure area $\left(20^{0}\right)$

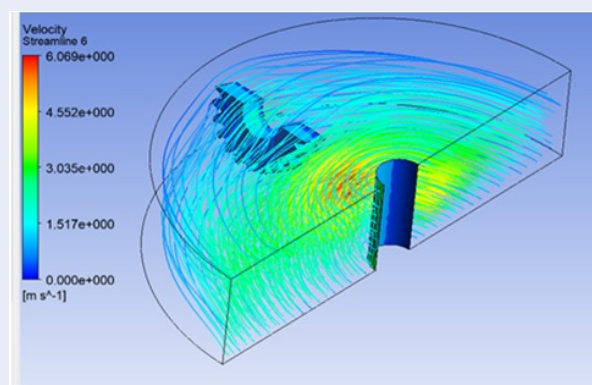

Figure 15: Streamline and velocity of $\operatorname{STFP}\left(20^{0}\right)$

The IA of the gear was changed to $24^{0}$ in this section. The generated pressure on the tooth surfaces were indicated in Figure 16.

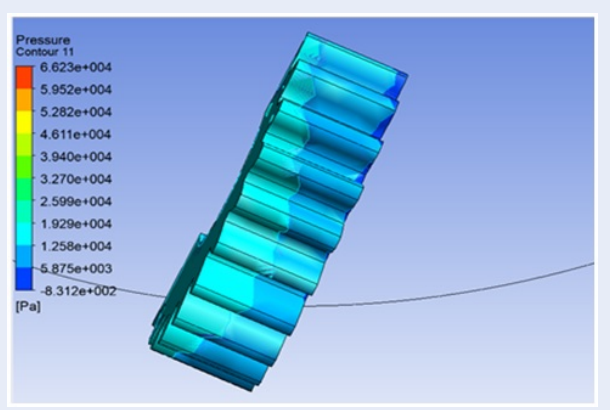

Figure 16: FEA results of distributed pressure area $\left(24^{0}\right)$

The pressure value on the gear surface was almost unchanged. The largest pressure can be reached about $15.25 \mathrm{kPa}$. In addition, the pressure zone at the rear of the workpiece was similar to that of the IA of $20^{\circ}$. The streamline and velocity of the machining fluid flow were presented in Figure 17. 


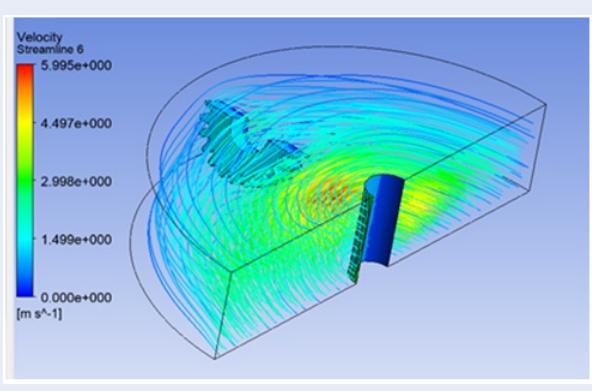

Figure 17: Streamline and velocity of STFP $\left(24^{0}\right)$

Figure 18 presents the measuring position on the one tooth surfaces. The 7 specific points on the tooth surface of the gears were set to be A, B, C, D, E, F and G, respectively.

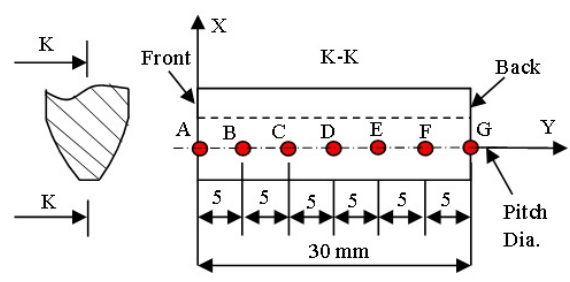

Figure 18: The measuring position on the one tooth surfaces

The simulation results of pressure distribution on the tooth surface in the case of inclination angles including $0,4,8,12,16,20$ and 24 degrees were shown in Figure 19.

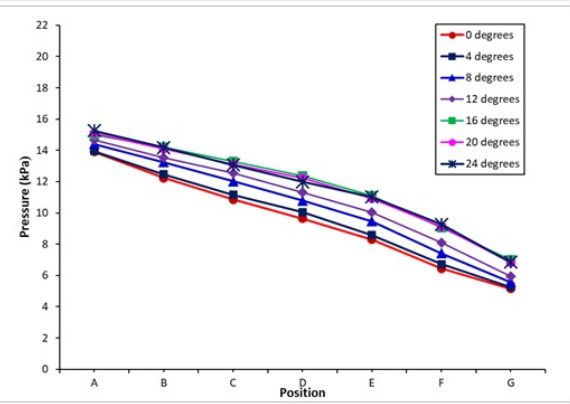

Figure 19: Pressure values at measuring position of tooth surface

As shown in Figure 19, the generated pressure appears only on the front of the gear surface when the IA of workpiece is changed from 0 to 8 degrees. Therefore, the abrasives slurry will not touch with the full thickness of the gear surface.

In order to improve the surface quality of the workpiece during polishing process, the IA of the gear needs to be increased. When the IA was set to be 16 degrees, the generated pressure will be applied on the entire gear surface. However, the pressure value is almost unchanged when the IA of workpiece exceeds 16 degree. In addition, the pressure value will be reduce in the posterior region of the tooth surface. From the FEA results, the suitable IA of workpieces should be set to 16 degrees in STFP process.

\section{Prediction of pressures with different pol- ishing speeds}

The generated pressure and the machining efficiency are dependent on the cutting speed values. For FE simulation, the polishing speeds were set to be 1.0, $1.25,1.5,1.75,2.0,2.25,2.5$ and $2.75 \mathrm{~m} / \mathrm{s}$, respectively. In addition, the IA of workpieces was chosen of 16 degree in this step. The generated pressure of workpieces with changing of polishing speed were shown in Figure 20.

As shown in Figure 20, the generated pressure on the workpiece surfaces increased with increasing of polishing speed. When the polishing speed was increased, the hydrodynamic pressure was produced and transferred to the abrasives. As a result, the applied force will be improved on the surface of the workpiece surfaces. Therefore, the surface roughness and machining efficiency were greatly improved. The generated pressure on different positions of the gear surfaces were illustrated in Figure 21.

In the polishing process, the points of $\mathrm{A}, \mathrm{B}$ and $\mathrm{C}$ will be in more favorable touch with the abrasives slurry because they are located at the top of the gear. Therefore, these points have the maximum pressure value. However, the polishing fluid will be difficult to reach the points of $D, E, F$ and $G$ due to the gap of the tooths. As a result, the pressure at these points will be smaller. In order to increase the polishing fluid touch with these points which located on the rear of the workpiece surfaces, the polishing speed must be reached the appropriate value. The generated pressure at the points of D, E, F and G will be significantly improved with increasing the polishing speed. When the polishing speed exceeds the permissible limit, the polishing liquid will be released out of the polishing tank due to the influence of centrifugal force. As a result, the abrasive slurry will be dry out and not touch with the workpiece surface during polishing process. Hence, the surface roughness of workpiece will not be improved. 


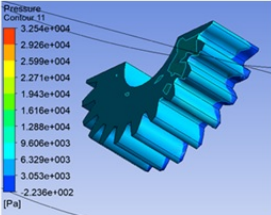

a. $1.0 \mathrm{~m} / \mathrm{s}$

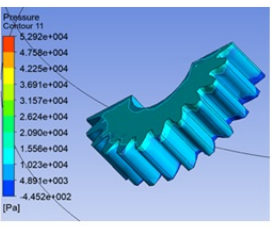

c. $1.5 \mathrm{~m} / \mathrm{s}$

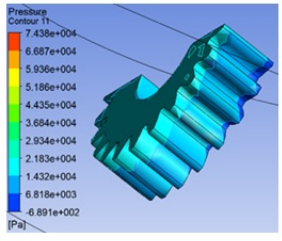

e. $2.0 \mathrm{~m} / \mathrm{s}$

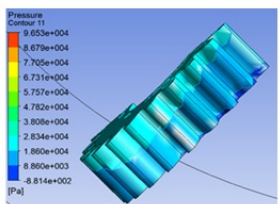

g. $2.5 \mathrm{~m} / \mathrm{s}$

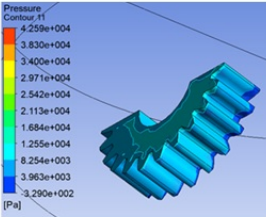

b. $1.25 \mathrm{~m} / \mathrm{s}$

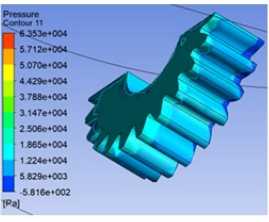

d. $1.75 \mathrm{~m} / \mathrm{s}$

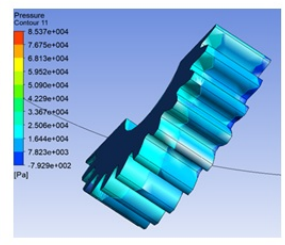

f. $2.25 \mathrm{~m} / \mathrm{s}$

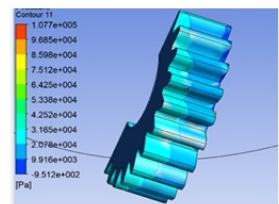

h. $2.75 \mathrm{~m} / \mathrm{s}$
Figure 20: The pressure on gear with different polishing speed

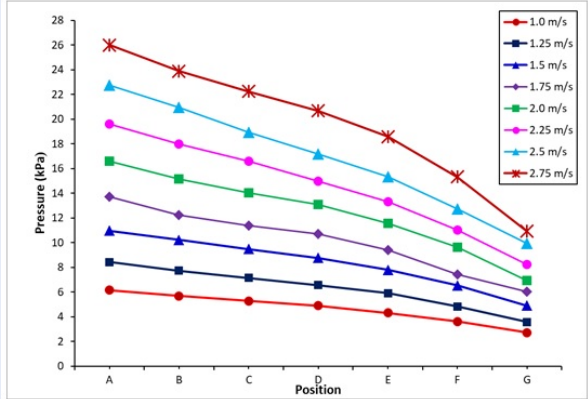

Figure 21: The generated pressure on different positions of gear.

\section{CONCLUSIONS}

In this work, the effects of the inclination angle and polishing speed on the generated pressure on the workpiece surfaces are proposed. The pressure distribution with variable of IA is first analyzed by FEA. When the IA of workpiece was set to be from 0 to $8 \mathrm{de}$ grees, the generated pressure appears only on the front of the gear surfaces. Therefore, the abrasives slurry will not touch with the full thickness of the gear surface. In order to improve the surface quality of the workpiece, the IA of the gear should be increased in machining process. The generated pressure will be applied on the entire gear surfaces with IA of 16 degree. The highest pressure can be reach about $14.88 \mathrm{kPa}$. However, the pressure value is almost unchanged and tends to decrease in the posterior region of the tooth surface when the IA of workpiece exceeds 16 degree. The results showed that the best surface roughness of workpiece can be reach with IA of $16^{\circ}$.

Furthermore, the generated pressure on the workpiece surfaces is greatly improved with increasing the cutting speed. The abrasive slurry have a greater pressure in the case of the polishing speed reaching the appropriate value. However, the polishing speed exceeds the allowable limit, the polishing fluid will be released out of the polishing tank due to the influence of centrifugal force. The results indicated that the abrasive slurry will not touch with the workpiece surfaces during polishing process. Therefore, the surface quality of workpiece can be decreased.

It is necessary to increase the polishing speed and inclination angle for improving the touch area of the polishing fluid with all positions of workpiece. As a result, the best surface roughness and machining efficiency can be reached. This suggests that the STFP method is a suitable method for polishing the complicated products.

\section{ACKNOWLEDGEMENT}

This research was funded by Vietnam National Foundation for Science and Technology Development (NAFOSTED) under Grant No. 107.03-2018.11.

\section{CONFLICT OF INTEREST}

The authors pledge that there are no conflicts of interest in the publication of the paper.

\section{AUTHOR CONTRIBUTION}

Dr. Duc Nam Nguyen presented the idea of study and carried out the collecting data, simulation and calculation analysis and writing the manuscripts. Dr. Hung Anh Ly participated in the scientific idea of 
research, reviewed the results of study. Dr. CongTruyen Duong contributed to review the calculation parameters, simulation conditions, results analysis and reviewing the paper.

\section{REFERENCES}

1. Maslov D, Danilevsky V, Sasov V. Engineering manufacturing processes in machine and assembly shops, translated from the Russian by Nicholas Weinstein. Mir Publishers: Moscow. 1967;

2. Tsay B, Liu Y, Yi-Chen C. Spur gear generation by shaper cutters. J Mater Process Technol. 2000;104:271-279. Available from: https://doi.org/10.1016/S0924-0136(00)00570-7.

3. Kim JD, Kim DS. Development of software for the design of a pinion cutter. J Mater Process Technol. 1997;68:76-82. Available from: https://doi.org/10.1016/S0924-0136(96)02544-7.

4. Hefeng B, Savage M, Knorr RJ. Computer modelling of rackgenerated spur gears. Mech Mach Theory. 1985;20(4):351360. Available from: https://doi.org/10.1016/0094-114X(85) 90040-0.

5. Das AK. Technological heredity in spur gear manufacturing. J Mater Process Technol. 1999;91:66-74. Available from: https: //doi.org/10.1016/S0924-0136(98)00432-4.

6. Vijayakar SM, Sarkar DR, Houser DR. Gear tooth profile determination from arbitrary rack geometry. Gear Technol. 1988;5(6):18-30.

7. Kuang $\mathrm{JH}$, Chen WL. Determination of tip parameters for the protuberance preshaving cutters. MechMach Theory. 1996;31(7):839-849. Available from: https://doi.org/10.1016/ 0094-114X(96)00026-2.

8. Bouzakis KD, Lili E, Michailidis N, Friderikos O. Manuf-acturing of cylindrical gears by generating cutting processes: a critical synthesis of analysis methods. CIRP Ann Manuf Technol. 2008;57:676-696. Available from: https://doi.org/10.1016/j. cirp.2008.09.001.

9. Özel C, İnan A, Özler L. An investigation on manufacturing of the straight bevel gear using end mill by CNC milling machine. J Manuf Sci Eng Trans ASME. 2005;127:503-511. Available from: https://doi.org/10.1115/1.1863256.

10. Özel C. Research of production times and cutting of the spur gears by end mill in CNC milling machine. Int J Adv Manuf Technol. 2011;54:203-213. Available from: https://doi.org/10. 1007/s00170-010-2943-5.

11. Özel C. A study on cutting errors in the tooth profiles of the spur gears manufactured in CNC milling machine. Int J Adv Manuf Technol. 2012;59:243-225. Available from: https://doi. org/10.1007/s00170-011-3475-3.

12. Shih $\mathrm{P}$, Chen D. A flank correction methodology for a five axis gear profile grinding machine. Mech Mach Theory. 2012;47:31-45. Available from: https://doi.org/10.1016/ j.mechmachtheory.2011.08.009.

13. Radzevich P, Krehel R. Determination of the grinding wheel profile and its setup for use in finishing cylindrical gears with an evolvent profile. Int J Adv Manuf Technol. 2012;63(912):875-879. Available from: https://doi.org/10.1007/s00170012-3982-x.

14. Liu P, Gong J, Wu T. Investigation on the grinding of elliptical gears with CNC conical wheel gear grinder. Int J Adv Manuf Technol. 2013;64(1-4):349-256. Available from: https: //doi.org/10.1007/s00170-012-4028-0.

15. Yi J, et al. A novel technique of polishing gear working surface using PECMP. Int J Precis Eng Manuf. 2009;10(4):57-62. Available from: https://doi.org/10.1007/s12541-009-0071-7.

16. Michalski J. Surface topography of the cylindrical gear tooth flanks after machining. Int J Adv Manuf Technol. 2009;63(56):513-528. Available from: https://doi.org/10.1007/s00170-
008-1737-5.

17. Shih $P$, Huang $C$, Lee $H$, Wu M. Manufacture of face- hobbed straight bevel gears using a six-axis CNC bevel gear cutting machine. Int J Adv Manuf Technol. 2013;68(9-12):2499-2515 Available from: https://doi.org/10.1007/s00170-013-4880-6.

18. Tang $Y$, Yin F, Chen $M$. The principle of profile modified face-gear grinding based on disk wheel. Mech Mach Theory. 2013;70:1-15. Available from: https://doi.org/10.1016/j. mechmachtheory.2013.06.013.

19. Wang $Y$, et al. A precision generating grinding method for face gear using CBN wheel. Int J Adv Manuf Tech. 2015;79:18391848. Available from: https://doi.org/10.1007/s00170-0156962-0.

20. Guo H, Peng X, Zhao N, Zhang X. A CNC grinding method and envelope residual model for face gear. Int J Adv Manuf Tech. 2015;79:1689-1698. Available from: https://doi.org/10.1007/ s00170-015-6915-7.

21. Lyu B, Dong C, Yuan J. Experimental study on shear thickening polishing method for curved surface. International Journal of Nanomanufacturing. 2017;13(1):81-95. Available from: https //doi.org/10.1504/IJNM.2017.082413.

22. Li M, et al. Shear-thickening polishing method. Int J Mach Tools Manuf. 2015;94:88-99. Available from: https://doi.org/ 10.1016/j.ijmachtools.2015.04.010.

23. Petel E, Hogan D. An investigation of shear thickening fluids using ejecta analysis techniques. Int J Impact Eng. 2016;93:39-48. Available from: https://doi.org/10.1016/j. ijimpeng.2016.02.001.

24. Galindo-Rosales J, Rubio-Hernández J, Sevilla A, Ewoldt H. How Dr. Malcom M. Cross may have tackled the development of -An apparent viscosity function for shear thickening fluids. J Non-Newton Fluid Mech. 2011;166(23-24):1421-1424. Available from: https://doi.org/10.1016/j.jnnfm.2011.08.008.

25. Melrose R, Ball C. Continuous shear thickening transitions in model concentrated colloids-The role of interparticle forces. J Rheol. 2004;48(5):937-960. Available from: https://doi.org/10. $1122 / 1.1784783$.

26. Brady F, Bossis G. The rheology of concentrated suspensions of spheres in simple shear flow by numerical simulation. J Fluid Mech. 1985;155:105-129. Available from: https://doi. org/10.1017/S0022112085001732.

27. Cheng X, McCoy H, Israelachvili N, Cohen I. Imaging the Microscopic Structure of Shear Thinning and Thickening Colloidal Suspensions. Science. 2011;333(6047):1276-1279. PMID: 21885778. Available from: https://doi.org/10.1126/science. 1207032.

28. Brown $E$, Jaeger $M$. Shear thickening in concentrated suspensions: phenomenology, mechanisms and relations to jamming. Rep Prog Phys. 2014;77(4):046602. PMID: 24695058. Available from: https://doi.org/10.1088/0034-4885/ 77/4/046602.

29. Laha A, Majumdar A. Interactive effects of $p$-aramid fabric structure and shear thickening fluid on impact resistance performance of soft armor materials. Mater Des. 2016;89:286293. Available from: https://doi.org/10.1016/j.matdes.2015.09. 077.

30. Zhang X, Li W, Gong X. The rheology of shear thickening fluid (STF) and the dynamic performance of an STF-filled damper. Smart Mater Struct. 2008;17(3):035027. Available from: https: //doi.org/10.1088/0964-1726/17/3/035027.

31. Crawford C, Williams S, Boldridge D, Liberatore W. Shear thickening of chemical mechanical polishing slurries under high shear. Rheol Acta. 2012;5(7):637-647. Available from: https: //doi.org/10.1007/s00397-012-0636-8.

32. Span J, Koshy P, Klocke F, et al. Dynamic jamming in dense suspensions: Surface finishing and edge honing applications. CIRP Annals. 2017:66(1):321-324. Available from: https://doi. org/10.1016/j.cirp.2017.04.082. 


\title{
Nghiên cứu mô phỏng mài bánh răng bằng chất lỏng phi Newton
}

\author{
Nguyễn Đức Nam ${ }^{1, *}$, Lý Hùng Anh ${ }^{2,3}$, Đường Công Truyền ${ }^{1}$
}

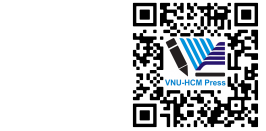

Use your smartphone to scan this QR code and download this article
${ }^{1}$ Khoa Công nghệ Cơ khí, Trường Đại học Công nghiệp Thành phố Hồ Chí Minh

${ }^{2}$ Khoa Kỹ thuật Giao thông, Trường Đại hoc Bách khoa

${ }^{3} Đ a ̣ i$ học Quốc gia Thành phố Hồ Chí Minh

Liên hệ

Nguyễn Đức Nam, Khoa Công nghệ Cơ khí, Trường Đại học Công nghiệp Thành phố Hồ Chí Minh

Email: nguyenducnam@iuh.edu.vn

Lịch sử

- Ngày nhận: 10-01-2020

- Ngày chấp nhận: 13-10-2020

- Ngày đăng: 22-10-2020

DOI : 10.32508/stdjet.v3i3.658

\section{Check for updates}

\section{Bản quyền}

๑ ĐHQG Tp.HCM. Đây là bài báo công bố mở được phát hành theo các điều khoản của the Creative Commons Attribution 4.0 International license.

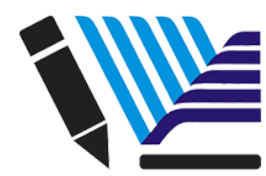

VNU-HCM Press

\section{TÓM TẮT}

Chất lỏng phi Newton là một loại chất lỏng biến tính được sử dụng để gia công các chi tiết có hình dạng phức tạp. Trong nghiên cứu này, phương pháp mới này được áp dụng để gia công bánh răng bằng thép hợp kim SCM435. Nguyên lý và hiệu quả của phương pháp gia công bằng chất lỏng phi newton đã được giới thiệu. Trong quá trình mài bóng, góc nghiêng của bánh răng là một trong những thông số ảnh hưởng lớn đến áp suất và chất lượng bể mặt tại các vị trí khác nhau trên bề mặt răng. Nó quyết định đến sự tiếp xúc giữa chất lỏng đánh bóng và bể mặt răng của bánh răng. Ảnh hưởng của góc nghiêng đến quá trình gia công được thực hiện bằng quá trình mô phỏng. Góc nghiêng của bánh răng như $0,4,8,12,16,20$ và 24 độ được sử dụng trong quá trình mô phỏng. Áp suất phấn bố trên bề mặt bánh răng và đặc tính dòng chất lỏng đánh bóng sẽ được trình bày và phân tích. Kết quả mô phỏng cho thấy góc nghiêng tốt nhất của bánh răng là khoảng 16 độ trong quá trình gia công. Vùng áp suất được phân phối trên hâuu hết bề mặt răng của bánh răng và giá trị áp suất tối đa đạt được khoảng 14,88 kPa. Ngoài ra, ảnh hưởng của tốc độ dòng chất lỏng mài bóng đến áp suất phân bố trên bề mă̆t bánh răng cũng được thực hiện trong nghiên cứu này khi góc nghiêng được thiết lập là 16 độ. Áp suất tác dụng lên phôi sẽ̉ tăng lên khi tốc độ mài bóng được tăng lên. Khi tốc độ mài bóng tăng lên, áp suất tác động lên các hạt mài làm cho nó tác động đến bề mặt phôi. Do đó, chất lượng bề mặt và hiệu quả gia công đạt được tốt hơn. Theo kết quả mô phỏng, phương pháp gia công này hứa hẹn và khả thi trong việc mài bóng bánh răng với hình dạng phức tạp.

Từ khoá: Chất lỏng phi Newton, Bề mặt bánh răng, Độ nhám bề mặt, Góc nghiêng, Áp suất, Tốc độ mài
Trích dẫn bài báo này: Nam $N D, A n h L H$, Truyền $D C$. Nghiên cứu mô phỏng mài bánh răng bằng chất lỏng phi Newton. Sci. Tech. Dev. J. - Eng. Tech.; 3(3):443-451. 